\title{
Journal of Management
}

http://jom.sagepub.com

\section{A Strategic Theory of the Firm as a Nexus of Incomplete Contracts: A Property} Rights Approach

Jongwook Kim and Joseph T. Mahoney

Journal of Management 2010; 36; 806 originally published online Mar 17, 2010;

DOI: $10.1177 / 0149206310363731$

The online version of this article can be found at:

http://jom.sagepub.com/cgi/content/abstract/36/4/806

\author{
Published by: \\ (S)SAGE \\ http://www.sagepublications.com \\ On behalf of: \\ S.MPA

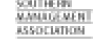 \\ Southern Management Association
}

Additional services and information for Journal of Management can be found at:

Email Alerts: http://jom.sagepub.com/cgi/alerts

Subscriptions: http://jom.sagepub.com/subscriptions

Reprints: http://www.sagepub.com/journalsReprints.nav

Permissions: http://www.sagepub.com/journalsPermissions.nav

Citations http://jom.sagepub.com/cgi/content/refs/36/4/806 
Journal of Management

Vol. 36 No. 4, July 2010 806-826

DOI: $10.1177 / 0149206310363731$

(C) The Author(s) 2010

\title{
A Strategic Theory of the Firm as a Nexus of Incomplete Contracts: A Property Rights Approach
}

\author{
Jongwook Kim \\ Western Washington University \\ Joseph T. Mahoney \\ University of Illinois at Urbana-Champaign
}

This article maintains that insights gained by joining property rights theory with Austrian economics can contribute to the dynamic capabilities literature by giving context to key constructs in the dynamic capabilities approach, particularly the nature of organizational processes and resource positions. By defining resources and capabilities as bundles of property rights, scholars can theoretically consider how firms develop, deploy, and renew those resources and capabilities by a process of bundling and rebundling resource combinations. Furthermore, central to bundling resource combinations is the contracting process, which generates information that leads to more efficient solutions that are achieved through intense bargaining and ingenuity, that in turn lead to discovery of new economic opportunities. However, in a world of positive transaction costs, the notion of the firm as a nexus of (complete) contracts is less useful for the authors' purposes; rather, the firm is defined as a nexus of incomplete contracts, which enables the possibility of entrepreneurial alertness and ingenuity. Thus, the authors maintain that the contracting process is a form of the entrepreneurial discovery process enabling firms to sense and seize new economic opportunities. Furthermore, the authors suggest that property rights

\footnotetext{
Acknowledgments: We thank Brandon Dupont, Nicolai Foss, Vinit Jagdish, Farrokh Kahnamoui, Peter Klein, and Tom Roehl for their insightful comments. We also thank Action Editor Michael Leiblein and two anonymous reviewers for suggestions and comments that improved the article. The usual disclaimer applies.
}

Corresponding author: Joseph T. Mahoney, University of Illinois at Urbana-Champaign, College of Business, Department of Business Administration, 140C Wohlers Hall, 1206 S. Sixth St., Champaign, IL 61820, USA

E-mail: josephm@uiuc.edu 
theory informs a contractual process-oriented approach for analyzing how dynamic capabilities are developed, sustained, and rejuvenated and in so doing intertwines firm boundary issues with the capabilities dimension of a strategic theory of the firm.

Keywords: dynamic capabilities; property rights; incomplete contracts; entrepreneurship

The dynamic capabilities approach seeks to overcome the static limitations of the resourcebased view (Eisenhardt \& Martin, 2000) by showing how organizational processes, resource positions, and path dependencies (Argyres \& Liebeskind, 1999) can lead to a stock of valuable, rare, inimitable, and nonsubstitutable resources - the so-called VRIN criteria (Barney, 1991). Compared to the resource-based view (Peteraf, 1993; Peteraf \& Barney, 2003), whose theoretical contribution defines formal conditions for sustainable economic profitability in equilibrium, the dynamic capabilities approach (Helfat et al., 2007; Teece, Pisano, \& Shuen, 1997) provides a more process-oriented (and nonequilibrium) focus. With this important distinction noted, however, these two theories are more connected than typically thought because the dynamic and process-oriented aspects of dynamic capabilities leading to economic rents are based on replicability and imitability conditions (Teece et al., 1997), which are similar to VRIN conditions (Barney, 1991).

To possess dynamic capabilities requires being able to identify potentially value-creating opportunities via absorptive capacity (Cohen \& Levinthal, 1990), entrepreneurial alertness (Kirzner, 1997), managerial capabilities (Adner \& Helfat, 2003), organizational learning (Zollo \& Winter, 2002), and relational capital (Dyer \& Singh, 1998). This process can be decomposed into how the firm senses market opportunities and seizes them, rejuvenating itself if necessary (Teece, 2007). Indeed, Winter (2003) emphasizes how purposeful activities develop and deploy such capabilities.

However, similar to criticisms of the resource-based view (Priem \& Butler, 2001), dynamic capabilities can also be criticized for being conceptually unclear and tautological (Williamson, 1999). What are dynamic capabilities? Furthermore, because the appropriation of economic rents is a critical element underemphasized in both dynamic capabilities and VRIN criteria and the firm boundary choice can influence this appropriation, a theory of firm-level economic rents and a theory of firm boundaries also share (market-friction) commonalities. Therefore, if dynamic capabilities confer economic rents on the firm in possession of these resources and capabilities, then it is critical to inquire about how one defines these resources and capabilities and defines the firm boundary in property rights terms.

The purpose of this article is to apply property rights theory in defining resources and capabilities as bundles of property rights. From this viewpoint, developing and renewing dynamic capabilities can be understood as a process of bundling (and rebundling) resource combinations. We submit that the contractual process reveals new information, which can lead to the recognition of new opportunities available in the market. Thus, firms can develop and renew resources and capabilities as a result of contractual bargaining processes. We maintain that at the heart of organizational processes that bring resource combinations together is the contracting process as a vehicle for discovery of new opportunities. Considering contracting processes as means to discover new opportunities (Kirzner, 1973) is the first stage of developing dynamic capabilities (Argyres \& Mayer, 2007). 
The extant research literature on dynamic capabilities emphasizes using intellectual property rights that require complementary and cospecialized assets (Teece, 1986) and the mobilization of these key resources within the firm to create economic value, resulting in organizational routines and best practices (Nelson \& Winter, 1982; Szulanski, 1996). But such resource combinations can offer only the potential for firm-level economic rents (J. Kim \& Mahoney, 2007). To link specific organizational processes that are the foundations of dynamic capabilities to how the firm might realize or capture economic rents, we must track contractual processes of bringing resource combinations together. Once economic value is created, that value must be captured (Coff, 1999), either through inherent attributes of resources (Lippman \& Rumelt, 1982) or by a combination of third-party enforcement and self-enforcing agreements (J. Kim \& Mahoney, 2002), which thus suggests focusing attention on appropriability concerns as well as a need for a feedback loop allowing for incentives to be set properly for economic value creation to occur initially.

Once economic value is created and captured through contracting processes, institutional norms may set in, formalizing certain practices even as informal practices adapt to changes (Jones, 1983; Poppo \& Zenger, 2002). The dynamic capability literature emphasizes relatively turbulent environments and how routines are formed and sustained in path-dependent processes (Arthur, 1994; Nelson \& Winter, 1982). A key characteristic of incomplete contracts that result from the evolving contracting process is that flexibility is already built in (Bernheim \& Whinston, 1998; Coase, 1937), particularly where those incomplete contracts are of a relational nature (Baker, Gibbons, \& Murphy, 2002; Macneil, 1980; Williamson, 1985).

Property rights theory provides a contractual process-oriented approach for how dynamic capabilities are developed, sustained, and rejuvenated and in so doing intertwines firm boundary issues with the capabilities dimension of a strategic theory of the firm (Mahoney, 2001; Rumelt, 1984). The current article suggests that such a theory of the firm, which incorporates insights from the dynamic capabilities approach and property rights theory, can conceptualize the firm as a "nexus of incomplete contracts." Indeed, just as the dynamic capabilities approach owes its intellectual antecedents to Austrian economics (Hayek, 1968; Kirzner, 1973), property rights theory (Alchian, 1977; Coase, 1960) emphasizes the evolutionary nature of competition and rule setting.

In the following sections, we first provide a brief review of the dynamic capabilities and property rights research literatures. Then follows a discussion of how property rights insights can contribute toward building a cogent theory of dynamic capabilities. Next, we propose a strategic theory of the firm based on property rights in combination with Austrian economics (Kirzner, 1973; Schumpeter, 1950) in developing a dynamic capabilities approach for the firm that accounts for both the creation and the distribution of economic value. The final section provides conclusions and a discussion.

\section{Establishing Property Rights}

\section{Contributions of Property Rights Theory}

Classical property rights theory (Alchian, 1977; Cheung, 1970; Coase, 1960; Demsetz, 1969; Furubotn \& Pejovich, 1972) provides a foundation for received theories in strategic management 
including transaction costs economics, the resource-based view, and dynamic capabilities (Mahoney, 2005). ${ }^{1}$ Furthermore, Coase's $(1937,1960)$ contributions provide a critique of neoclassical theory in a similar vein as Austrian economics - specifically, that the entrepreneurial process is being neglected (Makowski \& Ostroy, 2001). ${ }^{2}$ Indeed, Makowski and Ostroy (2001) note that although Austrians typically see the entrepreneurial or innovative side of economic actors in a positive light (e.g., entrepreneurial discovery), transaction costs and property rights theories (Coase, 1937, 1960) consider such creativeness as potential opportunism by economic actors. Hence, the flip side of opportunism may very well be opportunity (for flexibility), and vice versa. Therefore, extending Coase's (1960) insights on externalities, it is the entrepreneur's role to "internalize externalities" (Demsetz, 1967) in creative ways so that there are well-defined property rights, which facilitate economic value creation.

Although the focus of transaction costs theory has been matching transactional characteristics with appropriate governance mechanisms (Hennart, 1993; Williamson, 1996), the main concern of property rights theory, beginning with Coase (1960), has been attenuating inefficiency (deadweight social loss) at the economy level and the implications of property rights theory for public policy and the legal framework. A key insight of property rights theory is that the presence of externalities potentially interferes with competitive market processes and that a comparative analysis of markets, hierarchies, and government is required for attenuating negative externalities and for supporting positive externalities (Coase, 1937, 1960).

Taking a quite optimistic view, Demsetz (1967: 350) asserts that

property rights develop to internalize externalities when the gains of internalization become larger than the cost of internalization. Increased internalization, in the main, results from changes in economic values, changes which stem from the development of new technology and the opening of new markets, changes to which old property rights are poorly attuned. . . . The emergence of new private or state-owned property rights will be in response to changes in technology and relative prices.

However, more recent property rights analysis critiques this optimistic view for its lack of accounting for political processes in contracting for property rights and free-riding problems involved in group decision making (Eggertsson, 1990; J. Kim \& Mahoney, 2002; Libecap, 1989). Indeed, North (1981) suggests that the coercive power of the state has been employed throughout most of history in ways that have been inimical for obtaining improved property rights regimes and better economic growth.

Although transaction costs economics posits adaptive remedies to restore efficiency via markets, hierarchies, or some hybrid governance structure at the firm level (Williamson, 1996), property rights theory (Libecap, 1989; North, 1990) is less optimistic at the (nationstate) institutional level. Indeed, political decision-making processes at the institutional level are not typically efficient (J. Kim \& Mahoney, 2005; North, 1990). For example, in the case of oil field unitization in Texas, efficiency-enhancing agreements where aggregate economic gains were clearly large and positive were not achieved (J. Kim \& Mahoney, 2002; Libecap, 1989). 
The classical property rights literature, both empirically and theoretically (Alston, Eggertsson, \& North, 1996; North, 1990), acknowledges inefficiencies and the possibility of disequilibrium economic outcomes. Property rights theory, in fact, emphasizes both the struggles and achievements of economic decision makers for internalizing externalities and thereby considers the entrepreneurial processes whereby economic value is established through defining property rights in novel ways (Alchian, 1977; Barzel, 1997; Coase, 1960; K. Foss \& Foss, 2005).

The current article emphasizes that the processes whereby entrepreneurs internalize certain aspects of externalities through innovations in property rights (Alchian, 1977) are applicable to the organizational processes that are crucial for the development of dynamic capabilities (Teece et al., 1997). Furthermore, these processes of internalizing externalities go to the heart of how to define resources and are consistent with Penrose's (1959/1995) decidedly Austrian economics notion of the subjective opportunity set. We discuss these issues in more detail below, starting with the potential contributions of property rights theory informing the resource-based and dynamic capabilities approach (Miller \& Shamsie, 1996).

\section{Resources as Bundles of Property Rights}

Economic transactions are exchanges of bundles of property rights (Coase, 1960). It is not the physical property itself but the rights to certain aspects of that property that are exchanged. Property rights are "the rights of individuals to the use of resources .... supported by the force of etiquette, social custom, ostracism, and formal legally enacted laws supported by the states' power of violence or punishment" (Alchian, 1977: 129), and as such property rights define the nature of sanctioned norms of human behavior (Furubotn \& Pejovich, 1972). Thus, the property rights to use a resource may be held separately from the property rights to buy or sell that same resource. For instance, Alchian and Demsetz (1972) define ownership of the "classical capitalist firm" in property rights terms to include the following set of rights: (a) the right to appropriate economic returns from a resource (in team labor production the right to receive the residual income), (b) the right to use and change the form of the resource (in the case of labor the right to terminate or revise membership), and (c) the right to transfer the above-mentioned rights (i.e., alienability).

The theoretical insight that property rights are multifaceted and can be partitioned (Alchian, 1977; Ostrom, 1990) enables us to define resources as bundles of property rights. The way in which property rights are delineated can in effect set the rules for economic activities. Which partitions of property rights to a strategic asset are being utilized in a particular instance and how these various partitions are combined are at the heart of how firms generate and sustain firm-level capabilities (Argyres \& Liebeskind, 1998). Economic decision makers are expected to seek ways of partitioning property rights and transactions of bundles of these partitions to achieve more efficient solutions (Coase, 1960). ${ }^{3}$ Therefore, it is anticipated that property rights will be allocated to those who can generate greater economic value from the utilization of that particular set of property rights, foreshadowing the key outcome of the modern incomplete contracting models of Grossman and Hart (1986) and Hart and 
Moore (1990). Consistent with the Austrian view, greater economic value is achieved through a competitive discovery and bargaining process (Hayek, 1968). Furthermore, property rights are not static but rather can be reformulated, usually by an entrepreneur who is able to see potentially new valuable bundles of property rights (Barzel, 1997; K. Foss \& Foss, 2005).

The current article maintains that classical property rights theory (Alchian \& Demsetz, 1973; Cheung, 1983; Libecap, 1989) can contribute to the dynamic capabilities research literature by defining resources and capabilities as bundles of property rights (Coase, 1960). Property rights are sanctioned behavioral relations among decision makers in the use of potentially valuable resources. Property rights are social institutions that define or delimit the range of privileges granted to individuals to specific resources. Private ownership of these resources may involve a variety of human rights including the right to exclude nonowners from access, the right to appropriate the stream of economic rents from use of and investments in the resource, and the right to sell or otherwise transfer the resource to others (Alchian \& Demsetz, 1972). From property rights theory, resources that a firm "owns" are not the physical resources but rather are bundles of property rights. Their use involves domain partitioning (Alchian, 1977).

Defining resources and capabilities as partitioned bundles of property rights is useful not only for what such resources and capabilities are but also, more critically, for how they can confer economic rents to the firm as a result of developing and utilizing those resources and capabilities. In so doing, we can provide a theoretical basis for processes in developing and renewing capabilities. Furthermore, extending dynamic capabilities to better account for firm boundaries enables consideration of how firms create value as well as how-once created-firms can capture economic value.

Thus, dynamic capabilities can be conceptualized as organizational processes (integration or coordination, learning, and reconfiguration or transformation; Teece et al., 1997) and can be viewed as how entrepreneurial firms recombine partitions of property rights to adaptively respond to changes in the contracting environment. The insight that economic decision makers adapt to changes by reconfiguring property rights is at the heart of property rights theory (Coase, 1960; Demsetz, 1967; Pejovich, 1982). Moreover, Coasean bargaining (Coase, 1960), whereby economic decision makers seek more efficient bargaining outcomes, is seen as a discovery process in which information about the identity and bargaining positions of contracting parties is revealed through such a process. Through this process, the firm can sense new opportunities (Hayek, 1945).

Resources as a bundle of (partitions of) property rights are relevant for dynamic capabilities, particularly with regard to strategic complementary and cospecialized assets, which may be difficult to imitate or replicate via market mechanisms (Richardson, 1972; Teece, 1986). The dynamic capabilities approach posits that entrepreneurial and managerial capabilities enable assembling a particular mix of resources, which are subject to transactional difficulties (Teece, 1982). Taking the unbundling and reconfiguring of property rights to be outcomes of an endogenous bargaining process (Coase, 1960; Lippman \& Rumelt, 2003) gives context to resource positions in dynamic capabilities (Teece et al., 1997). Table 1 provides the key elements in dynamic capabilities. 
Table 1

Key Elements in Dynamic Capabilities

\begin{tabular}{|c|c|c|}
\hline $\begin{array}{l}\text { Key constructs in dynamic } \\
\text { capabilities }\end{array}$ & Direct antecedents & Contributions from property rights theory \\
\hline $\begin{array}{l}\text { Processes: } \\
\text { Coordination/Integration }\end{array}$ & $\begin{array}{l}\text { Transaction cost economics (integration } \\
\text { of external activities \& technologies); } \\
\text { Penrose, } 1959 \text { (subjective opportunity set) }\end{array}$ & $\begin{array}{l}\text { Combinations of partitions of property } \\
\text { rights (Alchian, 1977) as an adaptive } \\
\text { response }\end{array}$ \\
\hline Learning & Evolutionary economics (routines) & $\begin{array}{l}\text { Coasean (1960) bargaining process as a } \\
\text { discovery process }\end{array}$ \\
\hline $\begin{array}{l}\text { Reconfiguration/ } \\
\text { transformation }\end{array}$ & $\begin{array}{l}\text { Schumpeter (1934), Hayek (1945): new } \\
\text { combinations, divided knowledge }\end{array}$ & $\begin{array}{l}\text { Internalizing externalities (Coase, 1960; } \\
\text { Demsetz, 1967) }\end{array}$ \\
\hline $\begin{array}{l}\text { Positions: } \\
\text { Technological assets } \\
\text { Co-specialized assets } \\
\text { Financial assets } \\
\text { Locational assets }\end{array}$ & $\begin{array}{l}\text { Technology management (Henderson \& } \\
\text { Clark, 1990; Teece, 1986) }\end{array}$ & $\begin{array}{l}\text { Resources as a bundle of (partitions of) } \\
\text { property rights; particularly consistent } \\
\text { with co-specialized assets (systemic } \\
\text { view of strategic assets) }\end{array}$ \\
\hline $\begin{array}{l}\text { Paths: } \\
\text { Path dependencies } \\
\text { Technological opportunities }\end{array}$ & $\begin{array}{l}\text { Evolutionary economics, Alchian (1950) } \\
\text { Schumpeter (1934) }\end{array}$ & $\begin{array}{l}\text { Property rights theory/Economic history } \\
\text { (Libecap, 1989; North, 1990) }\end{array}$ \\
\hline Appropriability regime & $\begin{array}{l}\text { Intellectual property rights; technology } \\
\text { management (Oxley, 1999; Teece, } \\
\text { 1986); imitability (resource-based view) }\end{array}$ & $\begin{array}{l}\text { Arrow (1962) on intellectual property } \\
\text { rights; see Besen and Raskind (1991) } \\
\text { for a review }\end{array}$ \\
\hline Replicability \& imitability & $\begin{array}{l}\text { Resource-based view (Barney, 1991; } \\
\text { Kogut \& Zander, 1992; Lippman and } \\
\text { Rumelt, 1982; Peteraf, 1993) }\end{array}$ & $\begin{array}{l}\text { Varying extent of property rights over } \\
\text { resources (Alchian, 1977; Cheung, } \\
\text { 1968; Demsetz, 1964; Furubotn \& } \\
\text { Pejovich, 1972; Ostrom, 1990) }\end{array}$ \\
\hline Capabilities & $\begin{array}{l}\text { Penrose (1959): the services of resources, } \\
\text { not the resources themselves }\end{array}$ & $\begin{array}{l}\text { Coase (1960): Resources as bundle of } \\
\text { property rights }\end{array}$ \\
\hline
\end{tabular}

\section{Internalizing Externalities: Establishing Economic Value}

In dynamic capabilities terms, the development of these capabilities in turbulent environments is facilitated by organizational processes in reconfiguring and transforming the services of resources (Penrose, 1959/1995; Teece, 2007). In property rights terms, the process essentially internalizes externalities (Demsetz, 1967) so that decision makers capture the full extent of economic benefits and incur the full extent of their economic costs. An important example is the franchising contract in which economic hostages (i.e., collateral) and termination clauses internalize externalities so that the franchisee would bear the costs of poor performance, thus leading the franchisee to act in the interests of the franchisor (R. D. Blair \& LaFontaine, 2005). 
In general, property rights theory considers the costs of establishing rights over certain partitions of resources in the public domain (i.e., externalities and social costs) and the potential economic benefits of doing so (Barzel, 1997; Umbeck, 1981). Capturing economic value by establishing property rights over radio bandwidth (Coase, 1959)—selling advertising space on the Internet and e-commerce being modern analogues - is a useful illustration of entrepreneurial anticipation of potential economic value under genuine uncertainty (Knight, 1921).

Coase (1960) maintains that by treating externalities like any other factor of production, the bargaining process involved in arriving at a more efficient solution is made clearer. From property rights theory, resources and capabilities held by a firm are not necessarily the physical resources but rather are bundles of property rights. And as such, resources and capabilities can be unbundled and reconfigured to adaptively arrive at more efficient solutions to contractual problems (Chi, 1994). Through repeated exchange and learning, exchange partners can find new solutions resulting from new ways to cooperate and even integrate operations (Mahoney, 1995). Trust and loyalty are not traded on the market (i.e., are in the public domain) but nevertheless can be valuable assets (Arrow, 1974), and efforts to recognize and internalize these "externalities" are critical for supplier relationships. Placing certain aspects of property rights in the public domain (Barzel, 1997) — whether it is intended or emergentcan be a discovery process where the firm can potentially learn about new ways in which resources might be utilized via novel (re)combinations of bundles of property rights (J. Kim \& Mahoney, 2006). For instance, firms may experiment with the extent to which contractual provisions are well defined and sometimes may strategically leave some provisions intentionally ambiguous to retain flexibility for future contingencies (Barzel, 1997; Bernheim \& Whinston, 1998).

Salient for discussion on dynamic capabilities is how the economic value of property rights is established through a competitive market process where important knowledge and information, and thus new opportunities, are revealed to key decision makers. Furthermore, such a process is path dependent, with a series of adaptive responses being implemented over time, usually requiring creativity and learning (Alchian, 1950). Dynamic processes of institutional adaptive responses whereby property rights are established over valuable resources provide context to how resources and capabilities are renewed through Penrosean or Schumpeterian new combinations (Penrose, 1959/1995; Schumpeter, 1950).

\section{Property Rights and Dynamic Capabilities}

\section{Firm Boundaries}

The view of firm boundaries is an important difference between contractual theories of the firm (Coase, 1937; Williamson, 1985) and the resources and capabilities approach (Amit \& Schoemaker, 1993; Mahoney \& Pandian, 1992; Penrose, 1959/1995; Teece et al., 1997). Although contractual theories - prominently transaction costs theory ${ }^{4}$ - frame the question of firm boundaries in terms of the firm playing a transaction-cost economizing function, the resources and capabilities approach considers the possibility that differences in capabilities can partially explain firm boundaries (Argyres, 1996). ${ }^{5}$ 
One of the key contributions of the transaction costs theory of the firm in strategic management is that technical efficiencies notwithstanding, it is the transactional aspects that determine the choice of organizational forms or governance such as make or buy decisions (Williamson, 1975). Teece (1982) extends the transaction costs logic to multiproduct firms by clarifying the distinction between economies of scope and the scope of the diversified firm; where proprietary know-how or specialized indivisible resources, which are held in common, are leveraged across multiple businesses, integration is likely to be the efficient outcome. Williamson (1983) goes on to advance these ideas by emphasizing asset specificity and, by extension, ideas of exchanging mutual economic hostages in the form of mutual commitments via asset specificity to facilitate efficient exchange. In this way, transaction costs theory advances our understanding of the fundamental distinction between markets and hierarchies and between sales contracts and employment contracts (Simon, 1951; Williamson, 1975). The transaction costs economics framework considers the antecedents and consequences of different institutional settings.

Unlike transaction costs theory, which emphasizes firm boundaries, the resource-based view of the firm (Barney, 1986; Peteraf, 1993; Wernerfelt, 1984) does not directly deal with firm-level boundaries. However, Penrose (1959/1995) is quite clear in viewing the firm as an administrative, as well as a productive, hierarchy. In particular, Penrose (1959/1995) emphasizes organizational learning, entrepreneurial and managerial cognition, and the importance of tacit knowledge (Kor \& Mahoney, 2000; Mahoney, 1995; Teece, 1982). These ideas are consistent with the contractual aspect of how firm boundaries may be drawn because learning and cognition (e.g., dominant logic; Prahalad \& Bettis, 1986) have implications for contracting (Argyres \& Mayer, 2004; North, 2005).

The importance of tacit knowledge in Penrose (1959/1995) is more apparent when we consider managerial expectations and judgment under uncertainty and the firm's subjective opportunity set, which is a decidedly "Austrian" view with implications for the entrepreneurial function (N. J. Foss, Klein, Kor, \& Mahoney, 2008). Indeed, growth opportunities are enacted as a result of entrepreneurial foresight (Kor \& Mahoney, 2000). The difficulties in identifying entrepreneurial opportunities (and thus the economic value of entrepreneurial foresight) increase when the underlying resource in question is proprietary information such as technical know-how (Teece, 1982).

A central aspect of the so-called "Penrose effect" is an understanding of managerial attention and training as the limiting factor in the growth of the firm (Penrose, 1959/1995). Furthermore, some specific human capital is cospecialized to the physical capital owned by the firm (Hart, 1995; Pitelis, 1999). For Penrose (1959/1995), the cospecialization between human resources and a particular firm is a driver of the growth of the firm and, by extension, its existence. Teece (1982) is even more explicit about the market failures underpinning the growth opportunities advanced by Penrose (1959/1995) by emphasizing indivisible specialized physical capital and human capital as critical elements for extending firm boundaries (firm growth) and to fully utilize unused or underutilized resources, which are semipermanent ties to the firm.

Because resources are bundles of property rights (K. Foss \& Foss, 2005; J. Kim \& Mahoney, 2002), the entrepreneur's role in determining the services of resources of the firm is analogous to securing property rights to those underpinning resources. The firm, as an institution 
for bringing together distributed resources and capabilities, neither needs to own all the property rights to the underpinning resources and capabilities nor is it possible to do so. Indeed, the firm brings together combinations of resources and capabilities, which include varying extents of control (i.e., de jure rights vs. de facto rights, or formal vs. informal governance), so that the semi-permanent links between combinations of resources and capabilities (Wernerfelt, 1984) are governed by incomplete contracts (Aghion \& Bolton, 1992; Aghion \& Tirole, 1997).

In sum, transaction costs economics takes a broader view than Penrose (1959/1995) concerning contracting difficulties in coordinating economic activities across firm boundaries. That said, the limits of administrative and productive effectiveness that Penrose (1959/1995) emphasizes can be subsumed under the concept of transaction costs - for instance, the existence of the administrative unit because of the tacitness of the managerial function and stickiness in transferring managerial know-how quickly and effectively. Firm boundaries in the resources and capabilities approach, therefore, are limited by administrative and productive effectiveness, anticipating Barzel's $(1982,1987)$ measurement cost approach to entrepreneurship. The entrepreneur engages in complex activities for which the results are highly uncertain, and action is taken based on the subjective opportunity set (Penrose, 1959/1995) of the entrepreneur.

\section{Generating Economic Rents}

Another important distinction that can be made between transaction cost economics and (particularly Penrose's) resources and capabilities approach is that transaction costs theory focuses on economizing on governance costs (i.e., ex ante incentive provisions and ex post attenuation of opportunism), whereas the dynamic resource-based view deals with productionside efficiencies and dynamic capabilities. In transaction costs economics, a firm's economic rents have two primary sources: (a) economizing on the costs of transacting across firm boundaries and (b) capturing at least a part of the quasi-rents (Klein, Crawford, \& Alchian, 1978). The conventional resource-based logic indicates that economic profits that accrue from scarce resources (which are more efficient) are Ricardian rents (Peteraf, 1993). But economic profits in Penrose (1959/1995) are different from Ricardian rents, as the economic rents generated come from the firm's organizational capability to allocate (human capital) resources more effectively (Kor \& Mahoney, 2000; Prescott \& Visscher, 1980). Superior recognition of the "subjective opportunity set" of certain managers over others is the source of economic rents because managers who can seize new market opportunities will reap benefits from such entrepreneurial foresight (Kor, Mahoney, \& Michael, 2007; Penrose, 1959/1995). Therefore, Rumelt's (1987) concept of entrepreneurial rents more precisely captures the economic profit concept in Penrose's (1959/1995) resources approach. ${ }^{6}$ The concept of entrepreneurial rents is consistent with Austrian economics' antecedents of the dynamic capabilities approach with its emphasis on entrepreneurial alertness (Kirzner, 1973) and creative destruction (Schumpeter, 1950).

Just as the actual process of market competition is taken for granted in neoclassical theory (McNulty, 1968), the resource-based view (Barney, 1991; Peteraf, 1993) offers the formal static conditions for competitive advantage but does not go far enough in considering the 
processes whereby firms achieve such an advantage. Similar to transaction costs economics (and even more so, agency theory), the equilibrium orientation of the resource-based view implies that all alternatives and their consequences are known to the firm and it is a matter of overcoming market frictions to reach a stable equilibrium. This approach is not fully satisfactory, however, because competitive market processes entail searching for exchange partners and (price and nonprice) bargaining (Coase, 1937).

The competitive market process is a search for knowledge about the identity of trading partners and the conditions under which economically efficient transactions might take place (Coase, 1960) and how to bring together dispersed information to allocate resources and create economic value (Hayek, 1945). A key aspect of entrepreneurial discovery is knowledge of value (Kirzner, 1985), which entails not only an understanding of possible economic valuations under different contingencies but also an endogenous generation of new (growth) options. Austrian economics, and by extension the dynamic capabilities approach, views entrepreneurial alertness (Kirzner, 1973) and innovative capacity (Schumpeter, 1934) of firms as endogenous drivers of market competition, and this competitive process is a means for firms in the market to discover new knowledge that can be a source of economic profitability via new products or reformulating the value chain.

Property rights theory brings a contractual approach to the Austrian idea of entrepreneurial discovery (J. Kim \& Mahoney, 2006). The dynamic capabilities approach, following the Austrians, views the search for entrepreneurial rents as a discovery process, whereby feasible opportunities that had been hidden because of market incompleteness are uncovered (Denrell, Fang, \& Winter, 2003). Indeed, market incompleteness means that all possible potential products or services have not been created and that because of the absence of such products or services, we cannot place an economic value on that particular (as-yet-to-exist) product or service (Makowski \& Ostroy, 2001).

Similarly, in property rights theory, incomplete contracts that may allow opportunism (by one or more transacting parties) also may enable economic rents to be appropriated (Anderson \& Hill, 1991). Firms will, through the bargaining process, seek to capture property rights that remain in the public domain (Barzel, 1997; Demsetz, 1967). As exogenous price or technology conditions change, making property rights enforcement more feasible, firms seek to establish new property rights, which parallel the entrepreneurial process in the Austrian tradition and the organizational processes in the dynamic capabilities approach (Teece et al., 1997). Firms may also utilize such opportunities by leveraging existing complementary activities or capabilities (Denrell et al., 2003). Indeed, ingenious new contractual solutions (devising unrealized bundles of resources and capabilities) may be discovered through the competitive market process (Alchian, 1977). Table 2 provides a comparison of theoretical perspectives.

\section{Dynamic Capabilities and Property Rights—Toward a More Systemic View}

The previous section showed the usefulness of the property rights theory in joining dynamic capabilities with contractual approaches. We now consider the role of competitive contracting and organizational processes in developing and rejuvenating dynamic capabilities. We maintain that contracting processes are at the heart of creating and capturing value 
Table 2

Comparison of theoretical approaches

\begin{tabular}{llll}
\hline & $\begin{array}{c}\text { Transaction Costs } \\
\text { Economics }\end{array}$ & $\begin{array}{c}\text { Resource-Based } \\
\text { View (RBV) }\end{array}$ & $\begin{array}{c}\text { Penrosean RBV and Dynamic } \\
\text { Capabilities }\end{array}$ \\
\hline Firm boundaries & $\begin{array}{c}\text { Opportunism and } \\
\text { asset specificity } \\
\text { Quasi-rents } \\
\text { "Nature of the firm" }\end{array}$ & $\begin{array}{l}\text { Ricardian rents } \\
\text { Resources as a } \\
\text { Contributions from property } \\
\text { rights theory }\end{array}$ & $\begin{array}{l}\text { Administrative and productive } \\
\text { limits } \\
\text { Entrepreneurial rents } \\
\text { Capabilities as a bundle of } \\
\text { rights }\end{array}$ \\
\hline
\end{tabular}

as well as rejuvenating economic value over time. Thus, our theoretical focus considers how certain resource combinations might be implemented and how such combinations might be kept within the organization.

Central to dynamic capabilities (and to Austrian economics) is the firm's capacity to sense opportunities (Denrell et al., 2003; Penrose, 1959/1995) and to utilize them through organizational processes such as integration, learning, and reconfiguration or transformation (Teece et al., 1997). However, such capabilities are by definition difficult to predict ex ante, and this inability to predict might be considered a flaw as a theory (Kirzner, 1985). To address this possible flaw, a more precise definition of capabilities is needed to better account for organizational processes (Teece, 1996). Organizational processes in the form of routines (Nelson \& Winter, 1982) and patterned activities (Winter, 2003) give context to how such (dynamic) capabilities might be developed, such as implementing intangible resources (Itami, 1987), particularly intellectual capital that resides within human resources.

The capability to sense new opportunities requires access to information as well as the ability to recognize and shape opportunities (Teece, 2007). Property rights theory analyzes the property rights of resources and capabilities, which are established and bundled through a dynamic contractual process to realize greater economic efficiencies. ${ }^{7}$ This process is crucial for uncovering new information about the market and possibilities for economic value creation. Given the importance of users, suppliers, and even competitors for exchanging information and generating new knowledge, interactions across firm boundaries, whether formal or informal, are important sources of innovation (Von Hippel, 1988). Also crucial is the organizational capability to determine where in the organization certain decisions are made and how to control and provide the correct incentives (Hellmann, 1998; Jensen \& Meckling, 1992). Just as Hayek (1945) recommends the colocation of knowledge and decision-making authority, property rights models maintain that the control rights should reside with whoever can best utilize and have the most impact on the outcomes of the decisions (Grossman \& Hart, 1986; Hart \& Moore, 1990; Lerner \& Merges, 1998).

Once the firm has created economic value, it must next capture that value. Although the dynamic capabilities approach emphasizes economic value creation, transaction costs economics emphasizes capturing economic value (distribution). This article maintains that property rights theory is uniquely situated in that both economic value creation and the distribution of that value are simultaneously considered (Coase, 1988; J. Kim \& Mahoney, 2005). 
The establishment of institutions (Davis \& North, 1971; North, 1990) and the formation of property rights where legal rights are only imperfectly enforced (Libecap, 1989; Umbeck, 1981) are ways in which decision makers seek to establish rights over valuable property. This process of establishing property rights is also one of generating relevant information about bundles of property rights and about transactions, whether those rights are realized or remain unrealized. The situation where entrepreneurs observe and seek to mitigate the risk of opportunism brought on by contractual incompleteness can be a value-creating activity. The firm can be usefully thought of as a coalition of resource owners (Alchian, 1977), and it is the role of the entrepreneur to put together a value-creating combination as well as structure the relationship in a way that gets the economic incentives and governance right (Mahoney, 2005).

Furthermore, the dynamic capabilities approach and property rights theories are complementary: the more valuable the resources, the more incentives there are to make the property rights of resources more precise, and the more precisely delineated the property rights of resources, the more economically valuable the resources become (Libecap, 1989). Systems of property rights are, in essence, conduits through which value-creating activities are implemented so that resources can be channeled to higher yield uses, and asymmetric information and distributional conflicts need to be mitigated to help improve the likelihood of resources being channeled to these value-creating higher yield uses (J. Kim \& Mahoney, 2002).

\section{A Nexus of Incomplete Contracts: A Synthesis}

Theoretical developments in the resource-based and dynamic capabilities approach offer formal conditions for the creation and sustainability of firm-level economic rents, whereas transaction costs theory has advanced our understanding of firm boundaries (Mahoney, 2005). However, the dynamic capabilities approach is still at a nascent stage. The implicit assumption is that the firm controls the resources necessary to generate economic rents. However, because firms are viewed as coalitions of resource owners (Alchian, 1977; Coase, 1960), the firm's shareholders may have difficulty appropriating the economic rents, particularly if these resources are inalienable as is often the case with human capital. The nature of the firm in the dynamic capabilities approach emphasizes increasing the economic value of the firm's resource portfolio (Santos \& Eisenhardt, 2005), and property rights theory enables an institutional analysis of this competitive process.

The dynamic capabilities approach (Eisenhardt \& Martin, 2000; Teece \& Pisano, 1994) deals with institutions and technologies in the context of appropriability regimes (Teece, 1986). Although the legal and institutional frameworks may be mostly outside the control of individual firms, the parts that the firm can control in establishing property rights over resources and capabilities in novel ways are important concerns for the dynamic capabilities approach. By juxtaposing intellectual property rights (institutional and legal aspects) with inherent replicability (technical aspects), the dynamic capabilities approach joins the intellectual property rights regime with elements of managerial insight and decision making.

By combining insights from dynamic capabilities and property rights, we can now define the firm as a nexus of incomplete contracts. The idea of a nexus of complete contracts (Fama, 
1980 ) is rightly discarded in the dynamic capabilities approach (Teece et al., 1997) because it rules out competitive advantage, which requires market frictions. Moreover, a nexus of complete contracts allows for neither strategy nor surprises, thus eliminating the possibility of innovation or entrepreneurial alertness.

The coordination of resources and capabilities, whether within or across firm boundaries, is done through various (price and nonprice) mechanisms. Thus, rather than thinking of a continuum of ideal types (markets vs. hierarchies), economic activities (both within and across firm boundaries) can be understood as being coordinated by multiple mechanisms, and these organizational forms are typically hybrids (Hennart, 1993). Because of the complex nature of coalitions of resources and capabilities, many different coordination mechanisms are employed simultaneously, where some mechanisms may be closer to sales contracts and others are closer to employment contracts (Simon, 1951). Expanding the notion of contracts to include the employment relationship, we go beyond a complete contracting view of the firm to include incomplete and implicit, or relational contracts (Baker et al., 2002; Dyer \& Singh, 1998). Relationships governed by incomplete contracts are likely to concern resources and capabilities that are difficult to contract on, such as tacit know-how (Nelson \& Winter, 1982), or are highly cospecialized (Teece, 1986), so that the risk of economic holdup is high (Williamson, 1985). Indeed, economic rents require resources and capabilities that are nontradable or nonappropriable (Dierickx \& Cool, 1989; Eswaran \& Kotwal, 1985; Peteraf, 1993).

Incomplete contracts run the risk of various exchange hazards. The source of these hazards can come from asymmetric information and opportunism, which can require adaptive responses such as vertical integration or mutual credible commitments (S. M. Kim \& Mahoney, 2006; Williamson, 1983). In property rights terms, the existence of residual control rights (Grossman \& Hart, 1986) indicates the incompleteness of a contract. ${ }^{8}$ But this potential for exchange hazards masks the other side of the coin: There is also a potential for gain to the extent that the contract is incomplete. The value of "trust," where firms substitute "trust" for hierarchical control (Gulati, 1995; Kreps, 1990), is influenced by the extent to which the contract can retain flexibility in adapting to new situations (Bernheim \& Whinston, 1998).

A nexus of incomplete contracts typically implies that the firm has many different providers of resources and capabilities contributing to the value-creation process but with varying degrees of overlap in commitment and alignment of incentives. For instance, human resources employed by the firm cannot be owned by the firm, but the firm can exert control over certain aspects of human capital (Hart, 1995; Holmstrom, 1999; Wernerfelt, 2001). At the same time, those human resources providing highly specialized human capital to the firm may be able to appropriate economic rents from the firm. Such human resources do not necessarily enjoy residual claimant status, but by developing human capital that is cospecialized to the firm's critical assets, human resources can make themselves more economically valuable to the firm via access rights to other resources within the firm (Rajan \& Zingales, 1998). This dynamic interaction between the firm and specialized resources suggests the need for firms to continuously (re)configure their mix of resources to more fully capture the economic value created. Defining the firm as a nexus of incomplete contracts enables this process of continuous adaptation. 


\section{Conclusions}

One of the challenges of strategic management beyond theoretically explicating the formal conditions of sustainable competitive advantage is to explain and predict how the firm can build such an advantage, especially in a world of fast-paced technological, economic, and organizational changes. For the firm attempting to gain and sustain competitive advantage, it is a balancing act to create and/or exploit market opportunities (market frictions) but at the same time maintain stability once the competitive advantage is gained. Theoretical issues concerning the sustainability of economic rents are addressed by the VRIN criteria (Barney, 1991) and by the "four cornerstones" of competitive advantage (Peteraf, 1993) in the resourcebased view and by analysis of imitability and appropriability regimes in the dynamic capabilities approach (Teece et al., 1997). The dynamic capabilities approach delves deeper by considering organizational processes in which the firm brings together resources and capabilities in ways that create economic value via integration, reconfiguration or transformation, and learning. This focus on dynamic organizational processes emphasizes strategic managerial and entrepreneurial functions behind combinations of cospecialized assets (Teece, 1986) and combinative capabilities (Kogut \& Zander, 1992).

The current article maintains that property rights theory gives context to key constructs in the dynamic capabilities approach, in particular concerning the nature of organizational processes and resource positions. Property rights and legal frameworks are institutional mechanisms within which firms set ex ante incentives (agency theory), deal with ex post governance issues (transaction costs theory), and acquire and/or develop VRIN resources and capabilities (the resource-based and dynamic capabilities approach). Institutional and legal frameworks are macro-level environmental aspects of business decisions that are at least partially endogenous processes through which new knowledge can be brought together and new opportunities created (Makowski \& Ostroy, 2001; North, 2005; Schumpeter, 1934).

A key insight of property rights theory is that different specifications of property rights arise in response to resource allocation problems because of scarcity. This observation does not imply that an impersonal market mechanism inevitably drives toward an optimal outcome. Indeed, efficient outcomes are often achieved through intense bargaining (Coase, 1960) and sometimes from moments of ingenuity (Alchian, 1977; Demsetz, 1966), suggesting an active role for the firms whose strategic choices are the drivers for competitive market processes as well as for the organizational processes that seek to identify and exploit market opportunities.

By juxtaposing dynamic capabilities with property rights, we hope to introduce the contractual process as an avenue through which firms might discover new market opportunities. For instance, in interfirm relationships such as buyer-supplier relationships or strategic alliances, a contractual process of bundling and rebundling property rights should play a critical role in rejuvenating dynamic capabilities. How firms learn to contract more effectively over successive transactions (Argyres \& Mayer, 2004) is one example. The way firms exchange key control rights in interfirm contracts (Hellmann, 1998; Lerner \& Merges, 1998) is another. However, as pointed out in the previous sections, the contractual process is a way to discover key information (e.g., economic actors' preferences, potential economic value from potential resource allocation schemes, etc.), and therefore this notion can be extended to more general settings beyond just interfirm settings. 
In this way, determining firm boundaries is intertwined with entrepreneurial insight as a driver in the theory of the growth and economic profitability of firms. Although Penrose's $(1959 / 1995)$ theory of the growth of the firm - mostly in the context of diversification - did not fully consider contractual and institutional perspectives on firm boundaries, the modern dynamic capabilities research literature has incorporated transaction costs into the analysis (Argyres, 1996). ${ }^{9}$ The current article maintains that the seminal insights of Coase (1960) and Alchian (1977) concerning contractual processes as an entrepreneurial discovery process should stimulate even more conversation between these research literatures, particularly through systematic consideration of property rights theory. Therefore, it is anticipated that the next generation in the evolving science of organization will join property rights theory with Austrian economics and current economic foundations of strategy, which include transaction costs theory, evolutionary economics, and the dynamic capabilities approach.

\section{Notes}

1. Although property rights research by economic historians such as Libecap (1989) and North (1990) applied the theory to macro-level analysis, there is a large body of research literature in property rights that focuses on more micro-level phenomena (at the individual or firm level; Williamson, 2000).

2. Commons (1934) saw institutions as outcomes of (both formal and informal) conflict resolution. Commons viewed bargaining as an evolutionary process that established institutional rules as solutions. We are grateful to Action Editor Michael Leiblein for suggesting this link between the property rights literature and the old institutional economics of John R. Commons.

3. Although Coase's (1960) property rights approach can be reconstructed to be consistent with neoclassical (static) equilibrium, Coase never claimed that bargaining processes to attain equilibrium outcomes are instantaneous. In fact, Coase's view of the bargaining process is more consistent with (Austrian) dynamic processes and with the economic history of property rights (Libecap, 1989; North, 1990).

4. Transaction cost economics (Coase, 1937; Hennart, 1988; Teece, 1980; Williamson, 1996) is one of the prominent theories of the firm that is frequently drawn on in the strategic management literature. We deal with agency theory only tangentially as our focus is on firm boundaries.

5. Because the dynamic capabilities approach is driven by the firm's role in setting up its resource portfolio (Santos \& Eisenhardt, 2005), the nature of the resources themselves (e.g., similarity of underpinning knowledge base) is critical. However, even more fundamental is the contractual aspect of coordinating these combinations (Liebeskind, 1996; Mahoney, 2001).

6. Both the resource-based view of Barney (1991) and Peteraf (1993) and transaction costs theory emphasize economic profits in equilibrium. Moreover, the managerial rents concept of Castanias and Helfat (1991) is in the (static) equilibrium tradition. In contrast, Penrose (1959/1995) assumes economic profits in disequilibrium (N. J. Foss, 1999), which is consistent with the Austrian economics tradition (e.g., Kirzner, 1973; Schumpeter, 1934).

7. By extending the dynamic resources approach to consider the divergence between potential and realized economic rents, it is also possible to move beyond a shareholder perspective to encompass a broader stakeholder theory that has a solid property rights foundation (Asher, Mahoney, \& Mahoney, 2005; M. M. Blair, 1995; Donaldson \& Preston, 1995; J. Kim \& Mahoney, 2007; Zingales, 2000).

8. The key insight of the modern property rights model of Grossman and Hart (1986) is to minimize economic incentive dilution by giving the residual rights of control to the party who has the bigger impact on the total economic value that can be created by the collaboration between the two parties. Grossman and Hart's model of asset ownership that equates ownership with residual control rights is highly stylized because it precludes residual control rights being divided and hence precludes the possibility of shared ownership such as an equity joint ventures (J. Kim \& Mahoney, 2005). There are at least two economic elements critical for understanding ownership: 
residual control rights (Hart \& Moore, 1990) and residual rights to income or residual claimancy (Alchian \& Demsetz, 1972). The appropriate allocation of residual control rights mitigates ex post contractual hazards, whereas appropriately aligning residual claims mitigates ex ante contractual problems. Both residual control and residual claimancy (ex ante and ex post contractual) issues are at the heart of a definition of ownership (J. Kim \& Mahoney, 2005; Milgrom \& Roberts, 1992).

9. Indeed, recent research has emphasized the endogeneity between capabilities and governance modes (He, Mahoney, \& Wang, in press; Kor \& Mahoney, 2005; Leiblein, Reuer, \& Dalsace, 2002; Mayer \& Nickerson, 2005; Mayer \& Salomon, 2006; Nickerson \& Silverman, 2003; Wang, He, \& Mahoney, 2009). Similarly, the current article has emphasized the endogeneity between capability and property rights where the process of defining property rights is an organizational learning process (e.g., improving contacts and better managing exchange relationships; also see Agarwal, Croson, \& Mahoney, in press).

\section{References}

Adner, R., \& Helfat, C. 2003. Corporate effects and dynamic managerial capabilities. Strategic Management Journal, 24: 1011-1026.

Agarwal, R., Croson, R., \& Mahoney, J. T. in press. The role of incentives and communication in strategic alliances: An empirical investigation. Strategic Management Journal.

Aghion, P., \& Bolton, P. 1992. An incomplete contracts approval to financial contracting. Review of Economic Studies, 59: 473-494.

Aghion, P., \& Tirole, J. 1997. Formal and real authority in organizations. Journal of Political Economy, 105: 1-29.

Alchian, A. A. 1950. Uncertainty, evolution, and economic theory. Journal of Political Economy, 58: 211-221.

Alchian, A. A. 1977. Some economics of property rights. In A. A. Alchian, Economic forces at work: 127-149. Indianapolis, IN: Liberty Press.

Alchian, A. A., \& Demsetz, H. 1972. Production, information costs, and economic organization. American Economic Review, 62: 777-795.

Alchian, A. A., \& Demsetz, H. 1973. The property right paradigm. Journal of Economic History, 33: 16-27.

Alston, L. J., Eggertsson, T., \& North, D. C. 1996. Empirical studies in institutional change. New York: Cambridge University Press.

Amit, R., \& Schoemaker, P. J. H. 1993. Strategic assets and organizational rent. Strategic Management Journal, 14: 33-46.

Anderson, T. L., \& Hill, P. J. 1991. The race for property rights. Journal of Law and Economics, 33: 177-197.

Argyres, N. S. 1996. Evidence on the role of firm capabilities in vertical integration decisions. Strategic Management Journal, 17: 129-150.

Argyres, N. S., \& Liebeskind, J. P. 1998. Privatizing the intellectual commons: Universities and the commercialization of biotechnology. Journal of Economic Behavior and Organization, 35: 427-454.

Argyres, N. S., \& Liebeskind, J. P. 1999. Contractual commitments, bargaining power, and governance inseparability: Incorporating history into transaction cost theory. Academy of Management Review, 24: 49-63.

Argyres, N. S., \& Mayer, K. 2004. Learning to contract: Evidence from the personal computer industry. Organization Science, 15: 394-410.

Argyres, N. S., \& Mayer, K. 2007. Contract design as a firm capability: An integration of the learning and transaction cost perspectives. Academy of Management Review, 32: 1060-1077.

Arrow, K. J. 1962. Economic welfare and the allocation of resources for invention. In R. Nelson (Ed.), The role and direction of innovative activity: Economic and social factors: 609-625. Princeton, NJ: National Bureau of Economic Research.

Arrow, K. J. 1974. The limits of organization. New York: Norton.

Arthur, W. B. 1994. Increasing returns and path dependence in the economy. Ann Arbor: University of Michigan Press.

Asher, C. C., Mahoney, J. M., \& Mahoney, J. T. 2005. Towards a property rights foundation for a stakeholder theory of the firm. Journal of Management and Governance, 9: 5-32.

Baker, G., Gibbons, R., \& Murphy, K. J. 2002. Relational contracts and the theory of the firm. Quarterly Journal of Economics, 117: 39-84. 
Barney, J. B. 1986. Strategic factor markets: Expectations, luck, and business strategy. Management Science, 42: 1231-1241.

Barney, J. B. 1991. Firm resources and sustained competitive advantage. Journal of Management, 17: 99-120.

Barzel, Y. 1982. Measurement costs and the organization markets. Journal of Law and Economics, 25: 27-41.

Barzel, Y. 1987. The entrepreneur's reward for self-policing. Economic Inquiry, 25: 103-116.

Barzel, Y. 1997. Economic analysis of property rights (2nd ed.). New York: Cambridge University Press.

Bernheim, D., \& Whinston, M. 1998. Incomplete contracts and strategic ambiguity. American Economic Review, 88: 902-932.

Besen, S. M., \& Raskind, L. J. 1991. An introduction to the law and economics of intellectual property. Journal of Economic Perspectives, 5: 3-27.

Blair, M. M. 1995. Ownership and control. Washington, DC: Brookings Institute.

Blair, R. D., \& LaFontaine, F. 2005. The economics of franchising. New York: Cambridge University Press.

Castanias, R. P., \& Helfat, C. E. 1991. Managerial resources and rents. Journal of Management, 17: 155-171.

Cheung, S. N. S. 1968. Private property rights and sharecropping. Journal of Political Economy, 76: 1107-1122.

Cheung, S. N. S. 1970. The structure of contract and the theory of a non-exclusive resource. Journal of Law and Economics, 13: 49-70.

Cheung, S. N. S. 1983. The contractual nature of the firm. Journal of Law and Economics, 26: 1-21.

Chi, T. 1994. Trading in strategic resources: Necessary conditions, transaction cost problems, and choice of exchange partners. Strategic Management Journal, 18: 271-290.

Coase, R. H. 1937. The nature of the firm. Economica, 4: 386-405.

Coase, R. H. 1959. Federal communications commission. Journal of Law and Economics, 2: 1-40.

Coase, R. H. 1960. The problem of social cost. Journal of Law and Economics, 3: 1-44.

Coase, R. H. 1988. The firm, the market, and the law. Chicago: University of Chicago Press.

Coff, R. W. 1999. When competitive advantage doesn't lead to performance. Resource-based theory and stakeholder bargaining. Organization Science, 10: 119-133.

Cohen, W. M., \& Levinthal, D. A. 1990. Absorptive capacity: A new perspective on learning and innovation. Administrative Science Quarterly, 35: 128-152.

Commons, J. R. 1934. Institutional economics: Its place in political economy. New York: Macmillan.

Davis, L. E., \& North, D. C. 1971. Institutional change and American economic growth. New York: Cambridge University Press.

Demsetz, H. 1964. The exchange and enforcement of property rights. Journal of Law and Economics, 3: 11-26.

Demsetz, H. 1966. Some aspects of property rights. Journal of Law and Economics, 9: 61-70.

Demsetz, H. 1967. Towards a theory of property rights. American Economic Review, 57: 347-359.

Demsetz, H. 1969. Information and efficiency: Another viewpoint. Journal of Law and Economics, 12: 1-22.

Denrell, J., Fang, C., \& Winter, S. G. 2003. The economics of strategic opportunity. Strategic Management Journal, 24: $977-990$

Dierickx, I., \& Cool, K. 1989. Asset accumulation and sustainability of competitive advantage. Management Science, 35: 1504-1511.

Donaldson, T., \& Preston, L. 1995. The stakeholder theory of the corporation: Concepts, evidence and implications. Academy of Management Review, 20: 85-91.

Dyer, J. H., \& Singh, H. 1998. The relational view: Cooperative strategy and sources of inter-organizational competitive advantage. Academy of Management Review, 23: 660-679.

Eggertsson, T. 1990. Economic behavior and institutions. New York: Cambridge University Press.

Eisenhardt, K. M., \& Martin, J. A. 2000. Dynamic capabilities: What are they? Strategic Management Journal, 21 : 1105-1121.

Eswaran, M., \& Kotwal, A. 1985. A theory of contractual structure in agriculture. American Economic Review, 75: 352-367.

Fama, E. F. 1980. Agency problems and the theory of the firm. Journal of Political Economy, 88: 288-307.

Foss, K., \& Foss, N. J. 2005. Resources and transaction costs: How property rights economics furthers the resourcebased view. Strategic Management Journal, 26: 541-553.

Foss, N. J. 1999. Edith Penrose, economics, and strategic management. In C. Pitelis (Ed.), The growth of the firm: The legacy of Edith Penrose: 147-164. Oxford, UK: Oxford University Press.

Foss, N. J., Klein, P. G., Kor, Y. Y., \& Mahoney, J. T. 2008. Entrepreneurship, subjectivism, and the resource-based view: Toward a new synthesis. Strategic Entrepreneurship Journal, 2: 73-94. 
Furubotn, E. G., \& Pejovich, S. 1972. Property rights and economic theory: A survey of recent literature. Journal of Economic Literature, 10: 1137-1162.

Grossman, S., \& Hart, O. 1986. The costs and benefits of ownership: A theory of vertical integration and lateral integration. Journal of Political Economy, 94: 691-719.

Gulati, R. 1995. Does familiarity breed trust? The implications of repeated ties on contractual choice in alliances. Academy of Management Journal, 38: 85-112.

Hart, O. 1995. Firms, contracts and financial structure. Oxford, UK: Clarendon.

Hart, O., \& Moore, J. 1990. Property rights and the nature of the firm. Journal of Political Economy, 98: 1119-1158.

Hayek, F. A. 1945. The use of knowledge in society. American Economic Review, 35: 519-530.

Hayek, F. A. 1968. Competition as a discovery procedure. Quarterly Journal of Austrian Economics, 5: 9-23.

He, J., Mahoney, J. T., \& Wang, H. in press. Firm capability, corporate governance and firm competitive behavior: A multi-dimensional framework. International Journal of Strategic Change Management.

Helfat, C. E., Finkelstein, S., Mitchell, W., Peteraf, M. A., Singh, H., Teece, D. J., et al. 2007. Dynamic capabilities: Understanding strategic change in organizations. Malden, MA: Blackwell.

Hellmann, T. 1998. The allocation of control rights in venture capital contracts. RAND Journal of Economics, 29 : 57-76.

Henderson, R. M., \& Clark, K. 1990. Architectural innovation: The reconfiguration of existing product technologies and the failure of established firms. Administrative Science Quarterly, 35: 9-30.

Hennart, J.-F. 1988. A transaction costs theory of equity joint ventures. Strategic Management Journal, 9: 361-374.

Hennart, J.-F. 1993. Explaining the "swollen middle": Why most transactions are a mix of market and hierarchy. Organization Science, 4: 529-547.

Holmstrom, B. 1999. The firm as a subeconomy. Journal of Law, Economics and Organization, 15: 74-102.

Itami, H., with Roehl, T. W. 1987. Mobilizing invisible assets. Cambridge, MA: Harvard University Press.

Jensen, M. C., \& Meckling, W. H. 1992. Specific and general knowledge, and organizational structure. In L. Werin \& H. Wijkander (Eds.), Contract economics: 251-274. Oxford, UK: Blackwell.

Jones, G. R. 1983. Transaction costs, property rights, and organizational culture: An exchange perspective. Administrative Science Quarterly, 28: 454-467.

Kim, J., \& Mahoney, J. T. 2002. Resource-based and property rights perspectives on value creation: The case of oil field unitization. Managerial and Decision Economics, 23: 225-245.

Kim, J., \& Mahoney, J. T. 2005. Property rights theory, transaction costs theory, and agency theory: An organizational economics approach to strategic management. Managerial and Decision Economics, 26: 223-242.

Kim, J., \& Mahoney, J. T. 2006. How property rights economics furthers the resource-based view: Resources, transactions costs and entrepreneurial discovery. International Journal of Strategic Change Management, 1: 40-52.

Kim, J., \& Mahoney, J. T. 2007. Appropriating economic rents from resources: An integrative property rights and resource-based approach. International Journal of Learning and Intellectual Capital, 4: 11-28.

Kim, S. M., \& Mahoney, J. T. 2006. Mutual commitment to support exchange: Relation-specific IT system as a substitute for managerial hierarchy. Strategic Management Journal, 27: 401-423.

Kirzner, I. M. 1973. Competition \& entrepreneurship. Chicago: University of Chicago Press.

Kirzner, I. M. 1985. Discovery and the capitalist process. Chicago: University of Chicago Press.

Kirzner, I. M. 1997. Entrepreneurial discovery and the competitive market process: An Austrian approach. Journal of Economic Literature, 35: 60-85.

Klein, B., Crawford, R. G., \& Alchian, A. A. 1978. Vertical integration, appropriable rents, and the competitive contracting process. Journal of Law and Economics, 21: 297-326.

Knight, F. H. 1921. Risk, uncertainty, and profit. Boston: Houghton Mifflin.

Kogut, B., \& Zander, U. 1992. Knowledge of the firm, combinative capabilities, and the replication of technology. Organization Science, 3: 383-397.

Kor, Y. Y., \& Mahoney, J. T. 2000. Penrose's resource-based approach: The process and product of research creativity. Journal of Management Studies, 37: 109-139.

Kor, Y. Y., \& Mahoney, J. T. 2005. How dynamics, management, and governance of resource deployments influence firm-level performance. Strategic Management Journal, 26: 489-496.

Kor, Y., Mahoney, J. T., \& Michael, S. C. 2007. Resources, capabilities and entrepreneurial perceptions. Journal of Management Studies, 44: 1187-1212. 
Kreps, D. M. 1990. Corporate culture and economic theory. In J. E. Alt \& K. A. Shepsle (Eds.), Perspectives on political economy: 90-143. New York: Cambridge University Press.

Leiblein, M. J., Reuer, J. J., \& Dalsace, F. 2002. Do make or buy decision matter? The influence of organizational governance on technological performance. Strategic Management Journal, 23: 817-833.

Lerner, J., \& Merges, R. P. 1998. The control of technology alliances: An empirical analysis of the biotechnology industry. Journal of Industrial Economics, 46: 125-156.

Libecap, G. D. 1989. Contracting for property rights. New York: Cambridge University Press.

Liebeskind, J. P. 1996. Knowledge, strategy and the theory of the firm. Strategic Management Journal, 17: 93-107.

Lippman, S. A., \& Rumelt, R. P. 1982. Uncertain imitability: An analysis of interfirm differences in efficiency under competition. Bell Journal of Economics, 13: 418-438.

Lippman, S. A., \& Rumelt, R. P. 2003. A bargaining perspective on resource advantage. Strategic Management Journal, 24: 1069-1086.

Macneil, I. R. 1980. The new social contract: An inquiry into modern contractual relations. New Haven, CT: Yale University Press.

Mahoney, J. T. 1995. The management of resources and the resource of management. Journal of Business Research, 33: 91-101.

Mahoney, J. T. 2001. A resource-based theory of sustainable rents. Journal of Management, 27: 651-660.

Mahoney, J. T. 2005. Economic foundations of strategy. Thousand Oaks, CA: Sage.

Mahoney, J. T., \& Pandian, J. R. 1992. The resource-based view within the conversation of strategic management. Strategic Management Journal, 13: 363-380.

Makowski, L., \& Ostroy, J. M. 2001. Perfect competition and the creativity of the market. Journal of Economic Literature, 39: 479-535.

Mayer, K. J., \& Nickerson, J. A. 2005. Antecedents and performance implications of contracting for knowledge workers. Organization Science, 16: 225-242.

Mayer, K. J., \& Salomon, R. M. 2006. Capabilities, contractual hazards, and governance: Integrating resourcebased and transaction cost perspectives. Academy of Management Journal, 49: 942-959.

McNulty, P. J. 1968. Economic theory and the meaning of competition. Quarterly Journal of Economics, 82: 639-656.

Milgrom, P., \& Roberts, J. 1992. Economics, organization and management. Englewood Cliffs, NJ: Prentice Hall.

Miller, D., \& Shamsie, J. 1996. The resource-based view of the firm in two environments: The Hollywood film studios from 1936 to 1977. Academy of Management Journal, 39: 519-543.

Nelson, R. R., \& Winter, S. G. 1982. An evolutionary theory of economic change. Cambridge, MA: Belknap.

Nickerson, J. A., \& Silverman, B. S. 2003. Why firms want to organize efficiently and what keeps them from doing so: Inappropriate governance, performance and adaptation in a deregulated industry. Administrative Science Quarterly, 48: 433-465.

North, D. C. 1981. Structure and change in economic history. New York: Norton.

North, D. C. 1990. Institutions, institutional change and economic performance. New York: Cambridge University Press.

North, D. C. 2005. Understanding the process of economic change. Princeton, NJ: Princeton University Press.

Ostrom, E. 1990. Governing the commons: The evolution of institutions for collective action. New York: Cambridge University Press.

Oxley, J. E. 1999. Institutional environment and the mechanisms of governance: The impact of intellectual property protection on the structure of inter-firm alliances. Journal of Economic Behavior and Organization, 38: 283-309.

Pejovich, S. 1982. Karl Marx, property rights school and the process of social change. Kyklos, 35: 383-407.

Penrose, E. T. 1995. The theory of the growth of the firm. Oxford, UK: Oxford University Press. (Original work published 1959)

Peteraf, M. 1993. The cornerstones of competitive advantage: A resource-based view. Strategic Management Journal, 14: 179-191.

Peteraf, M. A., \& Barney, J. B. 2003. Unraveling the resource-based triangle. Managerial and Decision Economics, 24: 309-323.

Pitelis, C. 1999. Edith's garden and a glass half-full: Further issues. In C. Pitelis (Ed.), The growth of the firm: The legacy of Edith Penrose: 309-319. Oxford, UK: Oxford University Press.

Poppo, L., \& Zenger, T. 2002. Do formal contracts and relational governance function as substitutes or complements? Strategic Management Journal, 23: 707-725. 
Prahalad, C. K., \& Bettis, R. A. 1986. The dominant logic: A new linkage between diversity and performance. Strategic Management Journal, 7: 485-501.

Prescott, E. C., \& Visscher, M. 1980. Organizational capital. Journal of Political Economy, 88: 446-461.

Priem, R. L., \& Butler, J. E. 2001. Is the resource-based "view" a useful perspective for strategic management research? Academy of Management Review, 26: 22-40.

Rajan, R., \& Zingales, L. 1998. Power in a theory of the firm. Quarterly Journal of Economics, 113: 387-432.

Richardson, G. B. 1972. The organisation of industry. Economic Journal, 82: 883-896.

Rumelt, R. P. 1984. Toward a strategic theory of the firm. In R. Lamb (Ed.), Competitive strategic management: 556-570. Englewood Cliffs, NJ: Prentice Hall.

Rumelt, R. P. 1987. Theory, strategy, and entrepreneurship. In D. Teece (Ed.), The competitive challenge: Strategies for industrial innovation and renewal: 137-158. Grand Rapids, MI: Ballinger.

Santos, F. M., \& Eisenhardt, K. M. 2005. Organizational boundaries and theories of organization. Organization Science, 16: 491-508.

Schumpeter, J. A. 1934. The theory of economic development: An inquiry into profits, capital, credit, interest, and the business cycle. New Brunswick, NJ: Transaction Publishing.

Schumpeter, J. A. 1950. Capitalism, socialism, and democracy. New York: Harper \& Row.

Simon, H. A. 1951. A formal theory of the employment relationship. Econometrica, 19: 293-305.

Szulanski, G. 1996. Exploring internal stickiness: Impediments to the transfer of best practice within the firm. Strategic Management Journal, 17: 27-43.

Teece, D. J. 1980. Economies of scope and the scope of the enterprise. Journal of Economic Behavior and Organization, 1: 223-247.

Teece, D. J. 1982. Towards an economic theory of the multi-product firm. Journal of Economic Behavior and Organization, 3: 39-63.

Teece, D. J. 1986. Profiting from technological innovation: Implications for integration, collaboration, licensing and public policy. Research Policy, 15: 285-305.

Teece, D. J. 1996. Firm organization, industrial structure, and technological innovation. Journal of Economic Behavior and Organization, 31: 193-224.

Teece, D. J. 2007. Explicating dynamic capabilities: The nature and microfoundations of (sustainable) enterprise performance. Strategic Management Journal, 28: 1319-1350.

Teece, D. J., \& Pisano, G. 1994. The dynamic capabilities of firms: An introduction. Industrial and Corporate Change, 3: 537-556.

Teece, D. J., Pisano, G., \& Shuen, A. 1997. Dynamic capabilities and strategic management. Strategic Management Journal, 18: 509-533.

Umbeck, J. R. 1981. A theory of property rights with applications to the California gold rush. Ames: Iowa State University Press.

Von Hippel, E. 1988. The sources of innovation. Oxford, UK: Oxford University Press.

Wang, H., He, J., \& Mahoney, J. T. 2009. Firm-specific knowledge resources and competitive advantage: The role of economic- and relationship-based employee governance mechanisms. Strategic Management Journal, 30: 1265-1285.

Wernerfelt, B. 1984. A resource-based view of the firm. Strategic Management Journal, 5: 171-180.

Wernerfelt, B. 2001. Why should the boss own the assets? Journal of Economics \& Management Strategy, 11: 473-485.

Williamson, O. E. 1975. Markets and hierarchies: Analysis and antitrust implications. New York: Free Press.

Williamson, O. E. 1983. Credible commitments: Using hostages to support exchange. American Economic Review, 73: 519-540.

Williamson, O. E. 1985. The economic institutions of capitalism: Firms, markets, relational contracting. New York: Free Press.

Williamson, O. E. 1996. The mechanisms of governance. Oxford, UK: Oxford University Press.

Williamson, O. E. 1999. Strategy research: Governance and competence perspectives. Strategic Management Journal, 20: 1087-1108.

Williamson, O. E. 2000. The new institutional economics: Taking stock, looking ahead. Journal of Economic Literature, 38: 595-613.

Winter, S. G. 2003. Understanding dynamic capabilities. Strategic Management Journal, 24: 991-995.

Zingales, L. 2000. In search of new foundations. Journal of Finance, 55: 1623-1653.

Zollo, M., \& Winter, S. G. 2002. Deliberate learning and the evolution of dynamic capabilities. Organization Science, 13: 339-351. 